\title{
Pesticides in Streams in the Tar-Pamlico Drainage Basin, North Carolina, 1992-94
}

By Michael D. Woodside and Kelly E. Ruhl

U.S. GEOLOGICAL SURVEY

Water-Resources Investigations Report 01-4067

Prepared as part of the

NATIONAL WATER-QUALITY ASSESSMENT PROGRAM

Raleigh, North Carolina

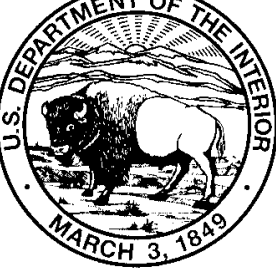




\section{U.S. DEPARTMENT OF THE INTERIOR \\ GALE A. NORTON, Secretary}

U.S. GEOLOGICAL SURVEY

CHARLES G. GROAT, Director

The use of firm, trade, and brand names in this report is for identification purposes only and does not constitute endorsement by the U.S. Geological Survey.

For addtional information write to:

Copies of this report can be purchased from:

District Chief

U.S. Geological Survey

3916 Sunset Ridge Road

Raleigh, NC 27607
U.S. Geological Survey

Branch of Information Services

Box 25286, Federal Center

Denver, CO 80225 


\section{FOREWORD}

The U.S. Geological Survey (USGS) is committed to serve the Nation with accurate and timely scientific information that helps enhance and protect the overall quality of life, and facilitates effective management of water, biological, energy, and mineral resources (http://www.usgs.gov/). Information on the quality of the Nation's water resources is of critical interest to the USGS because it is so integrally linked to the long-term availability of water that is clean and safe for drinking and recreation and that is suitable for industry, irrigation, and habitat for fish and wildlife. Escalating population growth and increasing demands for multiple water uses make water availability, now measured in terms of quantity and quality, even more critical to the long-term sustainability of our communities and ecosystems.

The USGS implemented the National WaterQuality Assessment (NAWQA) Program to support national, regional, and local information needs and decisions related to water-quality management and policy (http://water.usgs.gov/nawqa). Shaped by and coordinated with ongoing efforts of other Federal, State, and local agencies, the NAWQA Program is designed to answer: What is the condition of our Nation's streams and ground water? How are the conditions changing over time? How do natural features and human activities affect the quality of streams and ground water, and where are those effects most pronounced? By combining information on water chemistry, physical characteristics, stream habitat, and aquatic life, the NAWQA Program aims to provide science-based insights for current and emerging water issues and priorities. NAWQA results can contribute to informed decisions that result in practical and effective waterresource management and strategies that protect and restore water quality.

Since 1991, the NAWQA Program has implemented interdisciplinary assessments in more than 50 of the Nation's most important river basins and aquifers, referred to as Study Units (http://water.usgs.gov/nawqa/ nawqamap.html). Collectively, these Study Units account for more than 60 percent of the overall water use and population served by public water supply, and are representative of the Nation's major hydrologic landscapes, priority ecological resources, and agricultural, urban, and natural sources of contamination.
Each assessment is guided by a nationally consistent study design and methods of sampling and analysis. The assessments thereby build local knowledge about water-quality issues and trends in a particular stream or aquifer while providing an understanding of how and why water quality varies regionally and nationally. The consistent, multiscale approach helps to determine if certain types of waterquality issues are isolated or pervasive, and allows direct comparisons of how human activities and natural processes affect water quality and ecological health in the Nation's diverse geographic and environmental settings. Comprehensive assessments on pesticides, nutrients, volatile organic compounds, trace metals, and aquatic ecology are developed at the national scale through comparative analysis of the Study-Unit findings (http://water.usgs.gov/nawqa/ natsyn.html).

The USGS places high value on the communication and dissemination of credible, timely, and relevant science so that the most recent and available knowledge about water resources can be applied in management and policy decisions. We hope this NAWQA publication will provide you the needed insights and information to meet your needs, and thereby foster increased awareness and involvement in the protection and restoration of our Nation's waters.

The NAWQA Program recognizes that a national assessment by a single program cannot address all water-resource issues of interest. External coordination at all levels is critical for a fully integrated understanding of watersheds and for cost-effective management, regulation, and conservation of our Nation's water resources. The Program, therefore, depends extensively on the advice, cooperation, and information from other Federal, State, interstate, Tribal, and local agencies, nongovernment organizations, industry, academia, and other stakeholder groups. The assistance and suggestions of all are greatly appreciated.

$$
\begin{array}{r}
\text { Cobent n. Hevath } \\
\text { Robert M. Hirsch } \\
\text { Associate Director for Water }
\end{array}
$$




\section{CONTENTS}

Abstract …1...

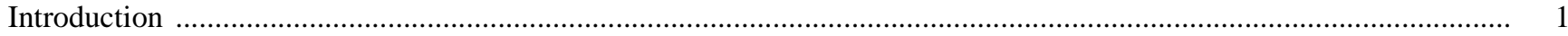

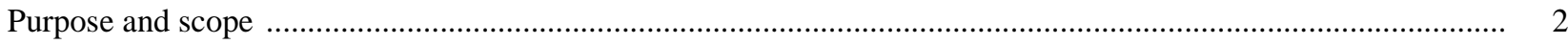

Description of the Tar-Pamlico drainage basin ..................................................................................... 2

Study approach .............................................................................................................................. 2

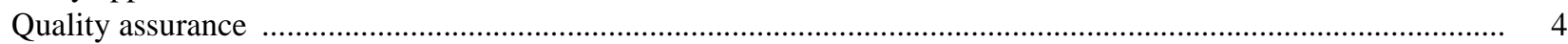

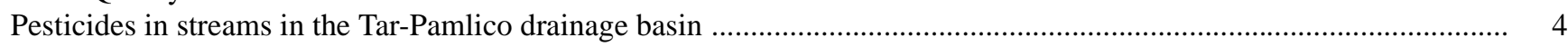

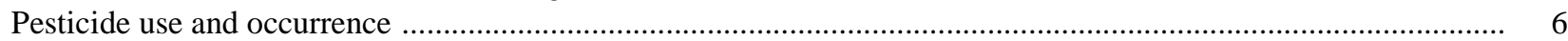

Temporal variability and detection frequencies of selected pesticides ............................................................. 8

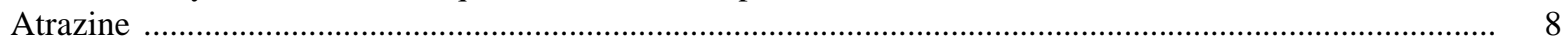

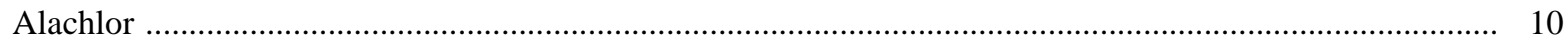

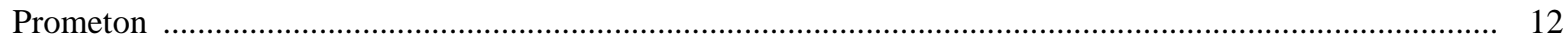

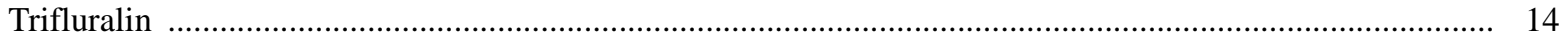

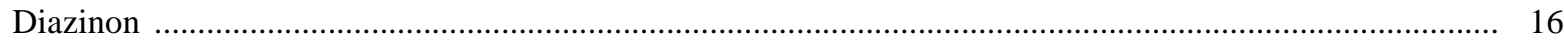

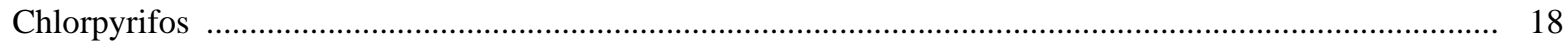

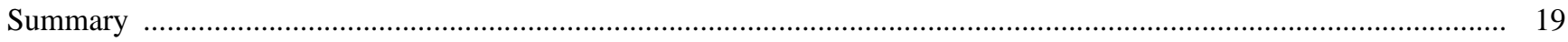

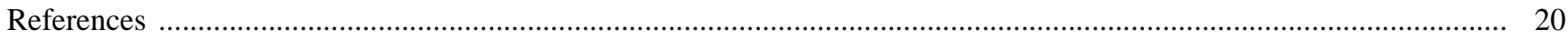

\section{Figures}

1. Map showing location of pesticide sampling sites in the Tar-Pamlico drainage basin, 1992-94 ....................... 3

2-15. Graphs showing:

2. Estimated pesticide use in 1990 for selected herbicides and insecticides in the

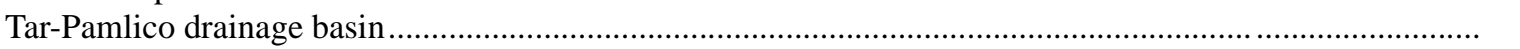

3. Adjusted detection frequencies for selected herbicides and insecticides in the Tar-Pamlico drainage basin

4. Seasonal variability of atrazine at five sites in the Tar-Pamlico drainage basin, 1992-94 ............................. 8

5. Comparisons of detection frequencies of atrazine in streams in the Tar-Pamlico drainage basin with streams in 62 agricultural, 22 urban, and 31 integrator sites throughout the Nation

6. Seasonal variability of alachlor at five sites in the Tar-Pamlico drainage basin, 1992-94

7. Comparisons of detection frequencies of alachlor in streams in the Tar-Pamlico drainage basin with streams in 62 agricultural, 22 urban, and 31 integrator sites throughout the Nation

8. Seasonal variability of prometon at five sites in the Tar-Pamlico drainage basin, 1992-94

9. Comparisons of detection frequencies of prometon in streams in the Tar-Pamlico drainage basin with streams in 62 agricultural, 22 urban, and 31 integrator sites throughout the Nation

\section{(3)}

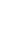
8

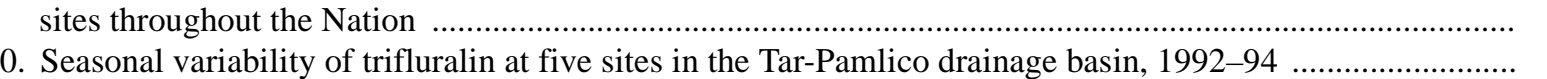

11. Comparisons of detection frequencies of trifluralin in streams in the Tar-Pamlico drainage basin with streams in 62 agricultural, 22 urban, and 31 integrator sites throughout the Nation

12. Seasonal variability of diazinon at five sites in the Tar-Pamlico drainage basin, 1992-94

13. Comparisons of detection frequencies of diazinon in streams in the Tar-Pamlico drainage basin with streams in 62 agricultural, 22 urban, and 31 integrator sites throughout the Nation

14. Seasonal variability of chlorpryifos at five sites in the Tar-Pamlico drainage basin, 1992-94

15. Comparisons of detection frequencies of chlorpyrifos in streams in the Tar-Pamlico drainage basin with streams in 62 agricultural, 22 urban, and 31 integrator sites throughout the Nation 
1. Descriptions of indicator and integrator sites sampled for pesticides in the Tar-Pamlico drainage basin, 1992-94

2. Pesticide data collected at indicator and integrator sites and estimated pesticide use in the

Tar-Pamlico drainage basin, 1992-94.

CONVERSION FACTORS AND ABBREVIATED WATER-QUALITY UNITS

\begin{tabular}{rcl}
\hline Multiply & by & To obtain \\
acre & Area & \\
square mile $\left(\mathrm{mi}^{2}\right)$ & 259.0 & hectare \\
square mile $\left(\mathrm{mi}^{2}\right)$ & 2.590 & hectare \\
& Volume & square kilometer \\
gallon (gal) & 3.785 & liter \\
& Mass & \\
ounce, avoirdupois (oz) & 28.35 & gram \\
pound, avoirdupois $(\mathrm{lb})$ & 0.4536 & kilogram \\
pound per square mile (lb/mi $\left.{ }^{2}\right)$ & 0.1751 & kilogram per square kilogram \\
\hline
\end{tabular}

\begin{abstract}
Abbreviated water-quality units: Chemical concentrations are given in metric units. Waterquality units are expressed in this report in micrograms per liter $(\mu \mathrm{g} / \mathrm{L})$.
\end{abstract}




\title{
Pesticides in Streams in the Tar-Pamlico Drainage Basin, North Carolina, 1992-94
}

\author{
By Michael D. Woodside and Kelly E. Ruhl
}

\section{ABSTRACT}

From 1992 to 1994, 147 water samples were collected at 5 sites in the Tar-Pamlico drainage basin in North Carolina and analyzed for 46 herbicides, insecticides, and pesticide metabolites as part of the U.S. Geological Survey's National Water-Quality Assessment Program. Based on a common adjusted detection limit of 0.01 microgram per liter, the most frequently detected herbicides were metolachlor (84 percent), atrazine (78 percent), alachlor (72 percent), and prometon (57 percent). The insecticides detected most frequently were carbaryl (12 percent), carbofuran (7 percent), and diazinon (4 percent). Although the pesticides with the highest estimated uses generally were the compounds detected most frequently, there was not a strong correlation between estimated use and detection frequency. The development of statistical correlations between pesticide use and detection frequency was limited by the lack of information on pesticides commonly applied in urban and agricultural areas, such as prometon, chlorpyrifos, and diazinon, and the small number of basins included in this study. For example, prometon had the fourth highest detection frequency, but use information was not available. Nevertheless, the high detection frequency of prometon indicates that nonagricultural uses also contribute to pesticide levels in streams in the TarPamlico drainage basin.
Concentrations of the herbicides atrazine, alachlor, and trifluralin varied seasonally, with elevated concentrations generally occurring in the spring, during and immediately following application periods, and in the summer. Seasonal concentration patterns were less evident for prometon, diazinon, and chlorpyrifos. Alachlor is the only pesticide detected in concentrations that exceeded current (2000) drinking-water standards.

\section{INTRODUCTION}

Pesticide use has increased tenfold in the last 25 years, and 75 percent of the pesticide use is related to agricultural production (Ware, 1989). Pesticides have become an integral part of crop management for controlling insects, weeds, fungi, and bacteria, and their use has increased crop production substantially. There are increasing concerns, however, about potential adverse effects of pesticides on water quality and the environment, and the effects of multiple pesticides in low concentrations on aquatic organisms are poorly understood.

Describing the occurrence and distribution of pesticides in the environment is one of the objectives of the U.S. Geological Survey's National Water-Quality Assessment (NAWQA) Program. As part of the NAWQA Program, an assessment of historical, current, and future water-quality conditions in a large, representative part of the Nation's surface- and groundwater resources is underway. The natural and human 
factors that affect the quality of these water resources are being examined (Leahy and others, 1990).

In 1991, the Albemarle-Pamlico drainage basin in North Carolina and Virginia was selected as one of the first 20 basins to be studied as part of the NAWQA Program. McMahon and Lloyd (1995) estimated that about 2.6 million pounds (lbs) of active ingredients in herbicides and 0.8 million lbs of active ingredients in insecticides were applied to crops grown in 1990 in the Albemarle-Pamlico drainage basin. Despite the large amounts of pesticides applied in the AlbemarlePamlico drainage basin, little information is available on the occurrence and temporal variability of concentrations of pesticides in surface waters in this basin (Harned and others, 1995). As part of the NAWQA Program, four small streams and one large river in the Tar-Pamlico drainage basin, which lies within the Albemarle-Pamlico drainage basin, were selected for study to assess the occurrence and seasonal distribution of pesticides, and to determine relations between agricultural pesticide use and concentrations of pesticides in streams.

\section{Purpose and Scope}

This report describes spatial and temporal patterns of pesticide concentrations in surface waters of the Tar-Pamlico drainage basin and includes an evaluation of the relation between pesticide use and the frequency of pesticide detection. The analyses presented in this report are based on water-quality data collected at five stream sites in the Tar-Pamlico drainage basin from 1992 to 1994 as part of the NAWQA Program. Estimates of pesticide use were compiled by multiplying recommended application rates by crop acreage. Crop acreage information was obtained from county-level estimates for 1990 and field-level records for 1994 from the U.S. Department of Agriculture.

\section{Description of the Tar-Pamlico Drainage Basin}

The Tar-Pamlico drainage basin encompasses about 7,400 square miles $\left(\mathrm{mi}^{2}\right)$ in central and eastern North Carolina (fig. 1). In 1990, the population of the counties and cities that are entirely or partially drained by streams in the Tar-Pamlico drainage basin was about 1.2 million people (McMahon and Lloyd, 1995). Land use in the basin consists of about 31 percent forested land, 28 percent open water, 24 percent agricultural land (cropland), 14 percent wetlands, and 3 percent developed land. The majority of the crops grown in the Tar-Pamlico drainage basin are grown in the eastern part of the basin, which drains the Coastal Plain Physiographic Province. The dominant crops grown in the basin in 1990 were soybeans (265,700 acres) and corn (218,200 acres). Other major crops included wheat $(108,400$ acres $)$, tobacco (51,200 acres), cotton (42,800 acres), and peanuts (45,400 acres).

\section{Study Approach}

Five water-quality sampling sites were selected in streams in the Tar-Pamlico drainage basin to assess the occurrence and temporal variability of selected pesticides in subbasins containing different mixtures and percentages of cropland. Four of these stream sites-Devil's Cradle Creek, Chicod Creek, Pete Mitchell Swamp, and Albemarle Canal—represent water-quality conditions in small basins (less than $71 \mathrm{mi}^{2}$ ) with cropland areas ranging from 12 to 57 percent of the total basin area (table 1; fig. 1). These sites are referred to as indicator sites because the quality of water at these sites is an indicator, or example, of inputs from one or two major land uses. The remaining site, Tar River, is referred to as an integrator site because water quality at this site represents the combined effects of discharges from wastewater-treatment plants, runoff from urban and cropland areas, and numerous other inputs from natural and manmade sources in a large basin $\left(2,222 \mathrm{mi}^{2}\right)$.

Water-quality samples were collected at the Chicod Creek indicator site from May to August 1992 and at the remaining sites from March 1993 to February 1994. At the four indicator sites, water samples were collected at least weekly, sometimes three times a week during the growing season, and monthly in the fall and winter. At the Tar River integrator site, water samples were collected every 2 weeks during the growing season and monthly during the fall and winter months.

General procedures for collecting water samples and cleaning equipment are described in Sandstrom (1990) and Manning and others (1994). Water samples were analyzed for 46 pesticides by using solid-phase extraction and analysis by capillary-column gas chromatography/mass spectrometry with the 

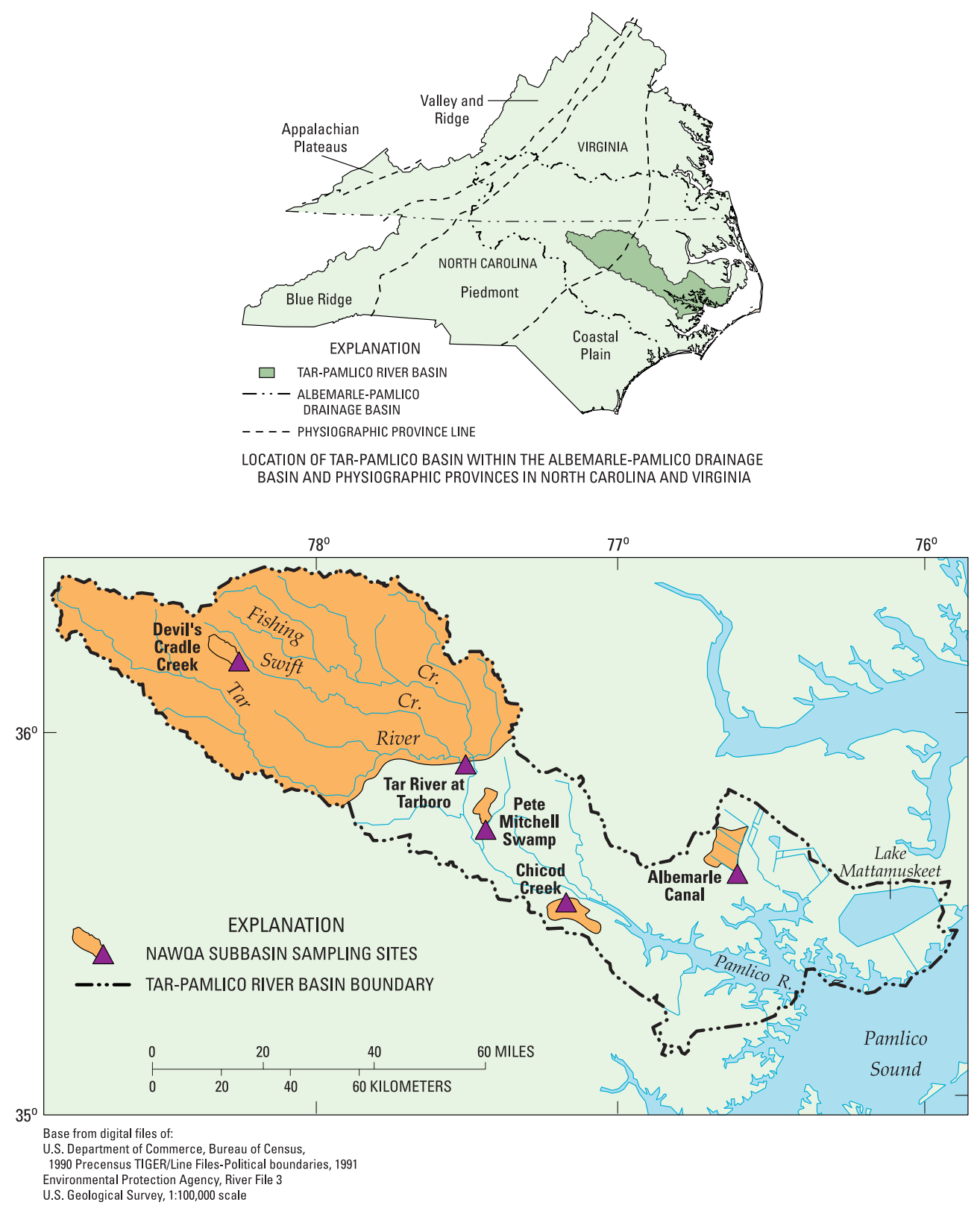

Figure 1. Location of pesticide sampling sites in the Tar-Pamlico drainage basin, 1992-94.

Table 1. Descriptions of indicator and integrator sites sampled for pesticides in the Tar-Pamlico drainage basin, 1992-94 [USGS, U.S. Geological Survey; $\mathrm{mi}^{2}$, square mile; SR, Secondary Road]

\begin{tabular}{lcccc}
\hline \multicolumn{1}{c}{ Site name } & $\begin{array}{c}\text { USGS site } \\
\text { number }\end{array}$ & $\begin{array}{c}\text { Drainage } \\
\text { area } \\
\left.\mathbf{( m i}^{2}\right)\end{array}$ & $\begin{array}{c}\text { Percentage } \\
\text { of } \\
\text { cropland }^{\mathbf{a}}\end{array}$ & Sampling period \\
\hline \hline Albemarle Canal near Swindell, N.C. & Indicator sites & & & March 1993 to February 1994 \\
Chicod Creek at SR 1760 near Simpson, N.C. & 02084558 & 71 & 57 & May 1992 to August 1992 \\
Devil's Cradle Creek at SR 1412 near Alert, N.C. & 02084160 & 42 & 31 & March 1993 to February 1994 \\
Pete Mitchell Swamp at SR 1409 near Penny Hill, N.C. & 02082731 & 13 & 12 & March 1993 to February 1994 \\
\hline & Integrator site & & \\
\hline Tar River at Tarboro, N.C. & 02083500 & 2,222 & 38 & March 1993 to February 1994 \\
\hline
\end{tabular}

${ }^{\text {a }}$ Cropland data for the indicator sites were compiled by using 1994 field records from the U.S. Department of Agriculture. Cropland data for the integrator site were compiled by Anderson and others (1976) from Land Use Data Analysis (LUDA) maps produced in the mid-1970's. 
monitoring of selected ions as described in Sandstrom and others (1992). The method detection limits and compound classes are listed in table 2 .

\section{Quality Assurance}

Approximately 15 percent of the analytical work consisted of quality-assurance samples, which included 11 field-blank and 7 field-spike samples. Field-blank samples are analyzed to ensure that (1) equipment has been adequately cleaned to minimize potential cross contamination introduced by samples obtained at previous sites; (2) sample collection and processing have not resulted in contamination; and (3) sample handling in the field and in the laboratory has not introduced contamination (Mueller and others, 1997). Field-spike samples are analyzed to determine bias as a result of matrix interference.

During this investigation, analysis of the fieldblank samples indicated that no systematic contamination occurred during sample collection and processing. Only 3 of the 46 pesticides analyzed were detected in 5 of 11 field-blank samples. Pronamide and p,p'-DDE were present in two field-blank samples but did not appear in the respective background environmental samples. Atrazine was detected in three field-blank samples. One field-blank sample had an atrazine concentration of 0.005 microgram per liter $(\mu \mathrm{g} / \mathrm{L})$, two orders of magnitude lower than the concentration detected in the associated environmental sample $(0.53 \mu \mathrm{g} / \mathrm{L})$. Atrazine concentrations measured in the other two field-blank samples were approximately three times less than the concentrations measured in the respective environmental samples. Even though these data indicate some atrazine contamination, interpretations and conclusions in this report are not likely to be affected because concentrations of atrazine in the field-blank samples were significantly less than concentrations in the environmental samples.

Recovery percentages for the field-spike samples indicated that analytical techniques generally provided conservative estimates of the 46 pesticides analyzed. Recovery percentages generally ranged from about 70 to 120 percent for most of the pesticides during the 1993 data-collection period. Recovery percentages were quite variable during the 1992 datacollection period at Chicod Creek because the laboratory method was still in the development phase.

\section{PESTICIDES IN STREAMS IN THE TAR- PAMLICO DRAINAGE BASIN}

The relation of occurrence of pesticides in streams to pesticide use was investigated in the TarPamlico drainage basin as part of the NAWQA study in the Albemarle-Pamlico drainage basin. In this section

Table 2. Pesticide data collected at indicator and integrator sites and estimated pesticide use in the Tar-Pamlico drainage basin, 1992-94

$\left[\mu \mathrm{g} / \mathrm{L}\right.$, microgram per liter; —, no data available; <, less than; *, pesticide metabolite; ${ }^{\circledR}$, pesticide with poor recovery performance]

\begin{tabular}{|c|c|c|c|c|c|c|}
\hline $\begin{array}{l}\text { Chemical } \\
\text { name }^{\mathrm{a}}\end{array}$ & $\begin{array}{l}\text { Trade } \\
\text { name }\end{array}$ & $\begin{array}{c}\text { Method } \\
\text { detection } \\
\text { limit, } \\
\text { in } \mu \mathrm{g} / \mathrm{L}\end{array}$ & $\begin{array}{l}\text { Frequency of } \\
\text { detection, } \\
\text { in percent } \\
(n=147)\end{array}$ & $\begin{array}{c}\text { Adjusted } \\
(0.01 \mu \mathrm{g} / \mathrm{L}) \\
\text { frequency of } \\
\text { detection, } \\
\text { in percent }\end{array}$ & $\begin{array}{l}\text { Maximum } \\
\text { concentration, } \\
\text { in } \mu \mathrm{g} / \mathrm{L}\end{array}$ & $\begin{array}{l}\text { Estimated use } \\
\text { in } 1990, \\
\text { in pounds }\end{array}$ \\
\hline \multicolumn{7}{|c|}{ Herbicides } \\
\hline Alachlor & Lasso & 0.002 & 76 & 72 & 3.2 & 130,300 \\
\hline Atrazine & AAtrex & .001 & 92 & 78 & 1.8 & 50,100 \\
\hline Benfluralin & Balan & .002 & 2 & 0 & .008 & - \\
\hline Butylate & - & .002 & 5 & 2 & .011 & 22,600 \\
\hline Cyanazine & Bladex & .004 & 14 & 10 & .079 & 5,600 \\
\hline DCPA & Dacthal & .002 & 5 & 1 & .026 & $<100$ \\
\hline Deethyl atrizine*@ & - & .002 & 35 & 5 & .026 & - \\
\hline Diethylanaline, 2,6-* & - & .003 & 27 & 1 & .014 & - \\
\hline
\end{tabular}


Table 2. Pesticide data collected at indicator and integrator sites and estimated pesticide use in the Tar-Pamlico drainage basin, 1992-94-Continued

[ $\mu \mathrm{g} / \mathrm{L}$, microgram per liter; —, no data available; <, less than; *, pesticide metabolite; ${ }^{@}$, pesticide with poor recovery performance]

\begin{tabular}{|c|c|c|c|c|c|c|}
\hline $\begin{array}{c}\text { Chemical } \\
\text { name }^{a}\end{array}$ & $\begin{array}{l}\text { Trade } \\
\text { name }\end{array}$ & $\begin{array}{c}\text { Method } \\
\text { detection } \\
\text { limit, } \\
\text { in } \mu \mathrm{g} / \mathrm{L}\end{array}$ & $\begin{array}{c}\text { Frequency of } \\
\text { detection, } \\
\text { in percent } \\
(n=147)\end{array}$ & $\begin{array}{c}\text { Adjusted } \\
(0.01 \mu \mathrm{g} / \mathrm{L}) \\
\text { frequency of } \\
\text { detection, } \\
\text { in percent }\end{array}$ & $\begin{array}{c}\text { Maximum } \\
\text { concentration, } \\
\text { in } \mu \mathrm{g} / \mathrm{L}\end{array}$ & $\begin{array}{c}\text { Estimated use } \\
\text { in 1990, } \\
\text { in pounds }{ }^{b}\end{array}$ \\
\hline \multicolumn{7}{|c|}{ Herbicides (Continued) } \\
\hline EPTC & Eptam & 0.002 & 1 & 1 & 0.022 & 19,800 \\
\hline Ethalfluralin & Sonalan & .004 & 1 & 0 & .006 & 5,900 \\
\hline Linuron & Lorox & .002 & 5 & 4 & .055 & 6,500 \\
\hline Metolachlor & Dual & .002 & 96 & 84 & 1.3 & 48,900 \\
\hline Metribuzin & Lexone & .004 & 35 & 25 & .26 & 2,100 \\
\hline Molinate & Ordram & .004 & 1 & 0 & .008 & - \\
\hline Napropamide & Devrinol & .003 & 28 & 22 & .18 & $<100$ \\
\hline Pebulate & Tillam & .004 & 1 & 0 & .001 & 1,900 \\
\hline Pendimethalin & Prowl & .004 & 11 & 3 & .015 & 20,900 \\
\hline Prometon & Pramitol & .018 & 68 & 57 & .68 & - \\
\hline Pronamide & Kerb & .003 & 1 & 1 & .43 & - \\
\hline Propachlor & Ramrod & .007 & 3 & 1 & .015 & - \\
\hline Propanil & Stampede & .004 & 1 & 0 & .006 & - \\
\hline Simazine & Princep & .005 & 70 & 30 & .2 & 8,800 \\
\hline Tebuthiuron & Spike & .01 & 28 & 22 & .18 & - \\
\hline Terbacil@ & Sinbar & .03 & 1 & 1 & .048 & - \\
\hline Thiobencarb & Bolero & .002 & 1 & 0 & .004 & - \\
\hline Triallate & Far-Go & .001 & 1 & 0 & .004 & - \\
\hline Trifluralin & Freflan & .002 & 27 & 3 & .048 & 10,100 \\
\hline \multicolumn{7}{|c|}{ Insecticides } \\
\hline Azinphos-methyl@ & Guthion & 0.03 & 2 & 1 & 0.054 & - \\
\hline Carbaryl@ & Sevin & .03 & 26 & 12 & .11 & 37,900 \\
\hline Carbofuran@ & Furadan & .02 & 8 & 7 & .048 & 16,500 \\
\hline Chlorpyrifos & Dursban & .004 & 12 & 3 & .011 & - \\
\hline DDE, p,p'-* & - & .006 & 11 & 1 & .01 & - \\
\hline Diazinon & Knox-Out & .002 & 16 & 4 & .062 & $<100$ \\
\hline Dieldrin & Panoram D-31 & .001 & 3 & 1 & .021 & Banned \\
\hline Disulfoton & Di-Syston & .017 & 0 & 0 & - & 1,800 \\
\hline Ethoprop & Mocap & .003 & 3 & 1 & .012 & 16,400 \\
\hline Fonofos & Dyfonate & .003 & 4 & 2 & .032 & - \\
\hline $\mathrm{HCH}$, alpha-* & - & .002 & 0 & 0 & - & Banned \\
\hline $\mathrm{HCH}$, gamma- & Lindane & .004 & 7 & 3 & .076 & Banned \\
\hline Malathion & Cythion & .005 & 4 & 2 & .067 & 800 \\
\hline Parathion, ethyl & Parathion & .004 & 0 & 0 & - & 900 \\
\hline Parathion, methyl & Penncap-M & .006 & 0 & 0 & - & 2,600 \\
\hline Permethrin, cis- & Ambush & .005 & 1 & 1 & .012 & - \\
\hline Phorate & Thimet & .002 & 3 & 3 & .033 & 9,800 \\
\hline Propargite & Comite & .013 & 3 & 1 & .013 & - \\
\hline Terbufos & Counter & .013 & 1 & 1 & .01 & - \\
\hline
\end{tabular}

${ }^{\text {a }}$ Chemicals in bold type rank within the top 10 of all herbicides and insecticides applied in the study basin, as estimated by McMahon and Lloyd (1995).

${ }^{\mathrm{b}}$ McMahon and Lloyd (1995). 
of the report, the occurrence of 46 pesticides in 4 indicator stream sites and 1 integrator stream site in the Tar-Pamlico drainage basin is related to general pesticide use in the basin. In addition, the variation in concentrations of four herbicides and two insecticides over time is described at each of these stream sites.

Estimates of pesticide use in each of the basins draining the selected sites in the Tar-Pamlico drainage basin were refined, based on 1994 field-level crop data, and related to how frequently these pesticides were detected at each site. Finally, detection frequencies at each site were compared to national detection frequencies compiled as part of the NAWQA Program for 62 agricultural sites, 22 urban sites, and 31 integrator sites across the Nation.

\section{Pesticide Use and Occurrence}

Based on estimated-use data from agricultural applications in 1990, a total of about 455,000 lbs of herbicides and about 90,700 lbs of insecticides were applied in the Tar-Pamlico drainage basin (McMahon and Lloyd, 1995). These estimates were calculated from agricultural inputs obtained by multiplying the recommended pesticide application rates by the county-level crop acreage data for 1990 and do not include nonagricultural uses. Herbicides with the highest estimated use in the Tar-Pamlico drainage basin were alachlor $(130,300 \mathrm{lbs})$, atrazine $(50,100 \mathrm{lbs})$, and metolachlor (48,900 lbs, table 2; fig. 2). Alachlor, atrazine, and metolachlor account for about 50 percent of the total herbicide use in the basin. Insecticides with the highest estimated use in the basin were carbaryl $(37,900 \mathrm{lbs})$, carbofuran (16,500 lbs), and ethoprop $(16,400 \mathrm{lbs})$, and these insecticides account for about 78 percent of the total insecticide use in the basin. Estimated pesticide use data for the 46 pesticides monitored during this study are listed in table 2 .

The occurrence and temporal variability of selected pesticides were monitored at four indicator sites and one integrator site in the Tar-Pamlico drainage basin as part of the NAWQA Albemarle-Pamlico study. From 1992 to 1994, 147 water samples were collected

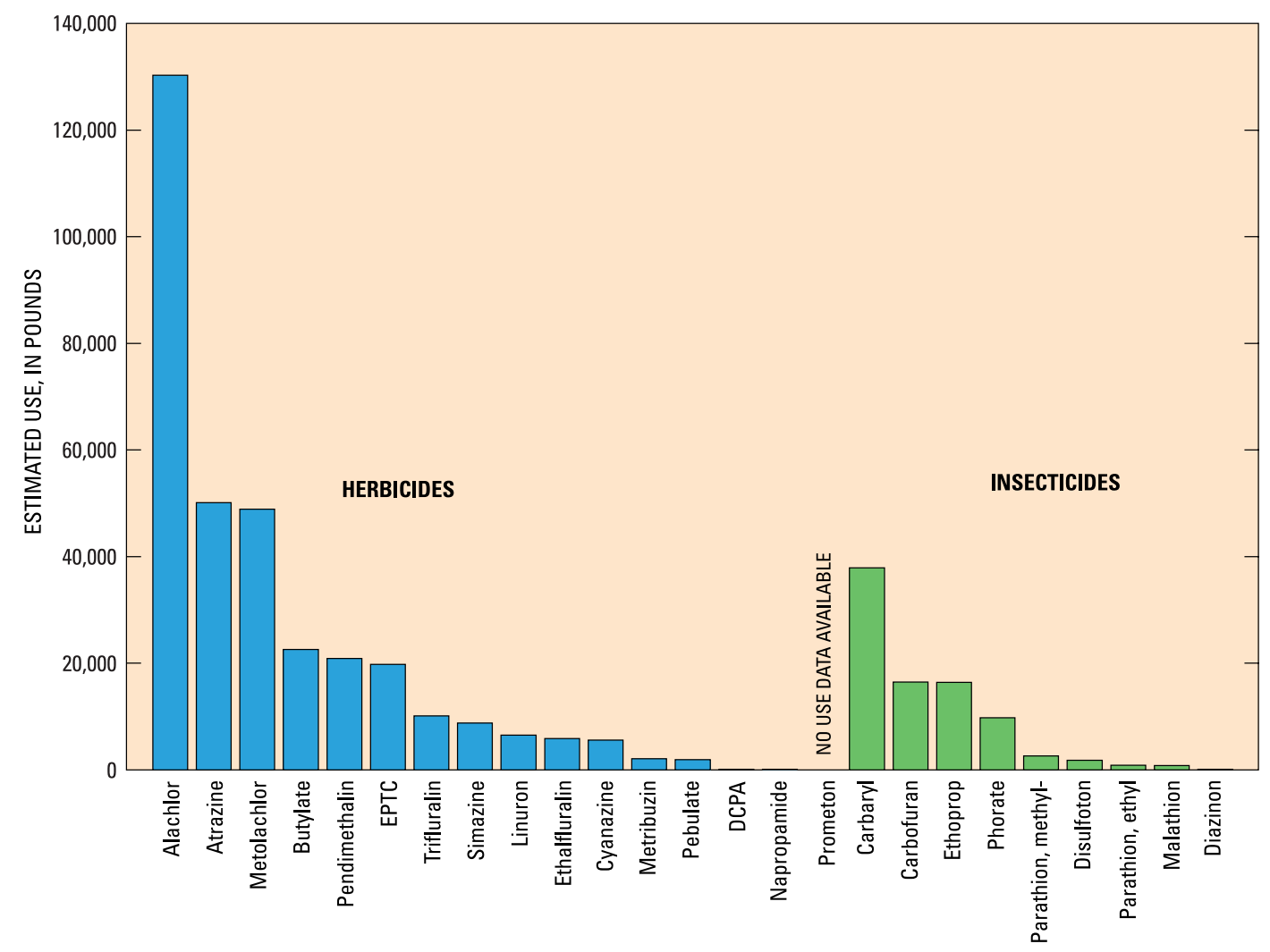

Figure 2. Estimated pesticide use in 1990 for selected herbicides and insecticides in the Tar-Pamlico drainage basin. 
and analyzed for 46 pesticides, including 25 herbicides, 17 insecticides, and 4 pesticide metabolites (table 2).

These 46 pesticides account for about 73 percent of the estimated herbicide use and 96 percent of the estimated insecticide use in the Tar-Pamlico drainage basin.

Previous studies indicate an inverse relation between method detection limits and pesticide detection frequencies (Barbash and Resek, 1996); thus, an adjusted detection limit of $0.01 \mu \mathrm{g} / \mathrm{L}$ was selected to compare detection frequencies among the 46 pesticides monitored during this study (fig. 3). Although eight of the monitored pesticides have method detection limits above $0.01 \mu \mathrm{g} / \mathrm{L}$, this adjusted limit was selected to include the majority of the pesticides monitored.

The herbicides most frequently detected, using the adjusted detection limit, were metolachlor (84 percent), atrazine (78 percent), alachlor (72 percent), and prometon (57 percent). As expected, herbicide use was somewhat related to the adjusted detection frequency in streams; however, the detection frequency could not be described completely by pesticide-use data. For example, metolachlor was the most frequently detected herbicide (fig. 3 ), but alachlor had the highest estimated use in the basin (fig. 2). The high adjusted detection frequency of prometon indicates that not all herbicide inputs are from agricultural sources. Prometon is used for nonagricultural purposes; thus, no estimated-use data are available.

The most frequently detected insecticides, using the adjusted detection limit of $0.01 \mu \mathrm{g} / \mathrm{L}$, were carbaryl (12 percent), carbofuran (7 percent), and diazinon (4 percent). Carbaryl and carbofuran also had the highest estimated uses among the insecticides.

Estimated uses of diazinon, based on agricultural inputs, probably are low because diazinon also is used to control insects in residential areas. Although ethoprop had the third highest estimated use (only $100 \mathrm{lbs}$ less than carbofuran), the detection frequency was only 1 percent.

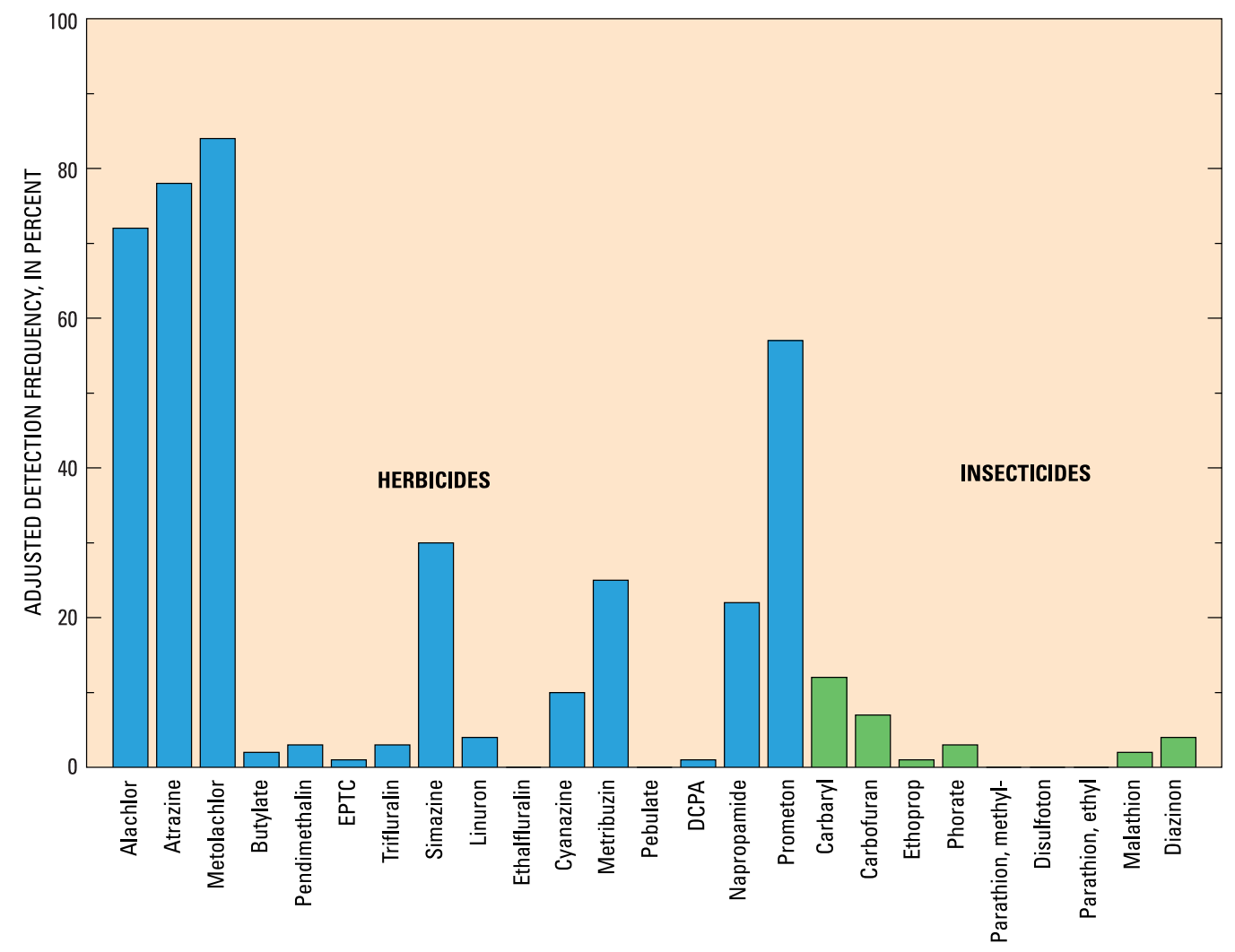

Figure 3. Adjusted detection frequencies for selected herbicides and insecticides in the Tar-Pamlico drainage basin. 


\section{Temporal Variability and Detection Frequencies of Selected Pesticides}

The temporal variability of concentrations of four herbicides and two insecticides at four indicator sites and one integrator site in the Tar-Pamlico drainage basin is discussed in this section. Additionally, relations between detection frequencies and pesticide use are described. Selected herbicides (atrazine, alachlor, prometon, and trifluralin) and insecticides (diazinon and chlorpyrifos) represent a range of factors related to pesticides, such as leaching potential, toxicity to fish, and detection frequency.

Field data for 1994 were used to refine estimates of atrazine, alachlor, trifluralin, and diazinon applied in each of the indicator basins to compare pesticide use with detection frequencies. No information was available for estimated uses of prometon or chlorpyrifos. U.S. Department of Agriculture field records for 1994 were used to estimate the type and amount of cropland in each indicator basin.

Estimates of pesticide use were compiled for each indicator basin by multiplying the recommended application rates by the 1994 crop-acreage data. The estimated pesticide-use data are based on agricultural use and do not represent pesticide applications on lawns, gardens, industrial sites, along roadways, or other nonagricultural areas where pesticides are applied. In addition, cropacreage data for 1994 may differ from the basin crop acreage during the sampling period. Because of the large basin size, pesticide-use estimates for the Tar River integrator basin were based on 1990 county-level data. Estimated pesticide uses were normalized by the size of the drainage basin to facilitate comparisons with detection frequencies.

Based on the method detection limit shown for each compound in table 2, detection frequencies of atrazine, alachlor, prometon, trifluralin, diazinon, and chlorpyrifos at sites in the Tar-Pamlico drainage basin were compared with detection frequencies in basins across the Nation that drain agricultural, urban, and mixed land uses (U.S. Geological Survey, 2000). The national detection frequencies are based on data collected at 62 agricultural indicator sites, 22 urban indicator sites, and 31 integrator sites sampled as part of the NAWQA Program.

\section{Atrazine}

Atrazine is used primarily as a selective postemergent herbicide to control weeds in corn and sorghum and also for nonselective weed control in nonagricultural areas. Concentrations of atrazine varied seasonally with maximum concentrations generally occurring during May and June, which corresponds to the post-emergent application period (fig. 4). None of the water samples collected at the four indicator sites or at the integrator site had concentrations of atrazine exceeding the maximum contaminant level (MCL) of $3 \mu \mathrm{g} / \mathrm{L}$ for drinking water (U.S. Environmental Protection Agency, 1996) or the aquatic-life guideline of $2 \mu \mathrm{g} / \mathrm{L}$ (Canadian Council of Resource and

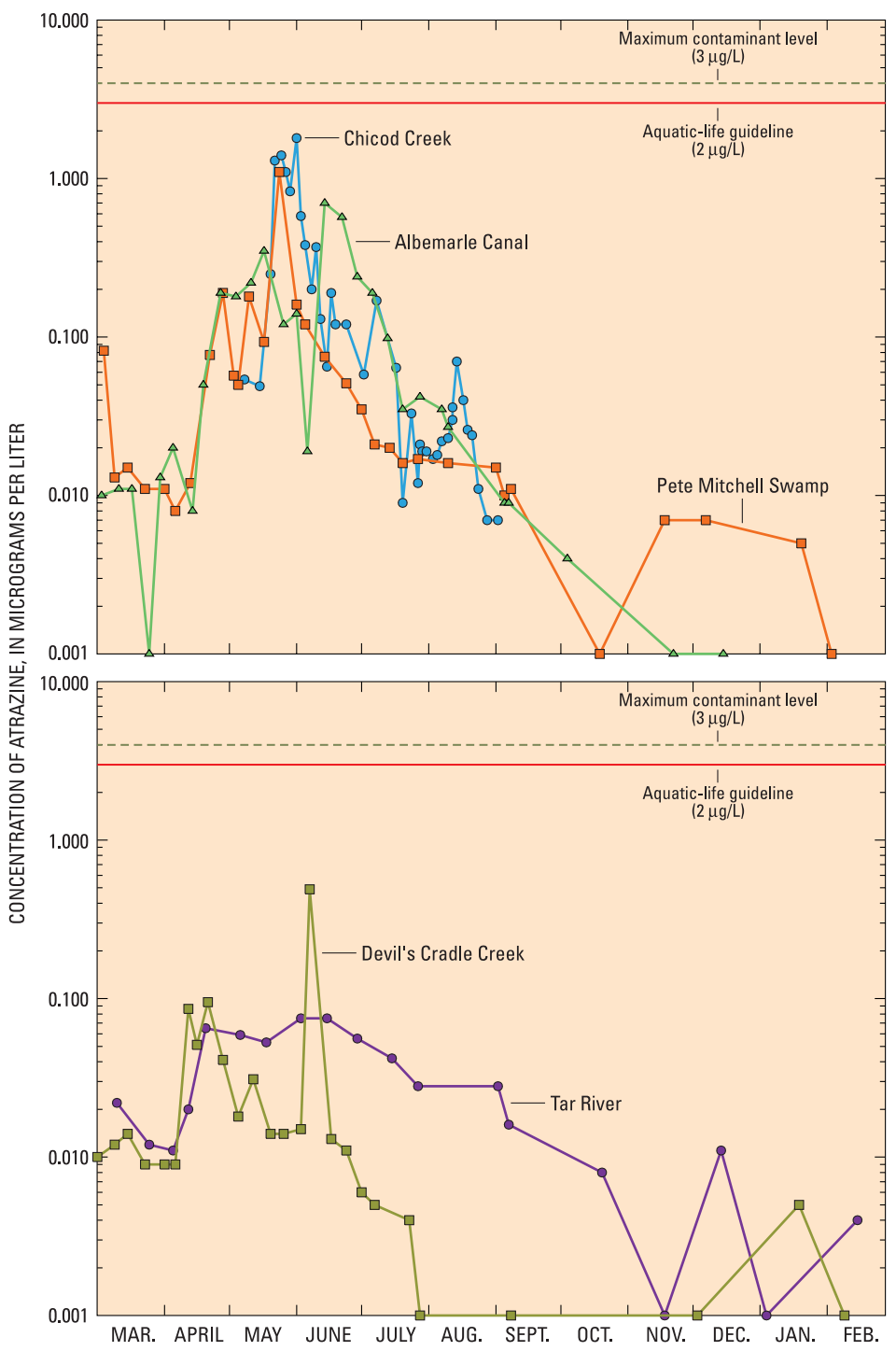

Figure 4. Seasonal variability of atrazine at five sites in the TarPamlico drainage basin, 1992-94. 
Environment Ministers, 1991). Concentrations of atrazine in Pete Mitchell Swamp and Albemarle Canal were similar to concentrations in Devil's Cradle Creek and Tar River from August to April. Concentrations of atrazine in Chicod Creek, Pete Mitchell Swamp, and Albemarle Canal generally ranged from 0.1 to $1.8 \mu \mathrm{g} / \mathrm{L}$ during May and June, coinciding with application periods. In Devil's Cradle Creek, concentrations of atrazine generally were less than $0.01 \mu \mathrm{g} / \mathrm{L}$ from July to March, whereas concentrations of atrazine in Tar River remained above $0.01 \mu \mathrm{g} / \mathrm{L}$ into September.

Estimated pesticide use, based on 1994 cropacreage data, provided limited information to describe the range of detection frequencies for atrazine.

Although the estimated use of atrazine varied from 1 to
159 pounds per square mile $\left(\mathrm{lbs} / \mathrm{mi}^{2}\right)$ among the five subbasins, atrazine was detected frequently at all sites, with detection frequencies ranging from 85 to 100 percent (fig. 5). Concentrations of atrazine were greater than or equal to $0.05 \mu \mathrm{g} / \mathrm{L}$ in about 30 percent or more of the samples collected at Albemarle Canal, Chicod Creek, Pete Mitchell Swamp, and Tar River; whereas, concentrations of atrazine were greater than or equal to $0.05 \mu \mathrm{g} / \mathrm{L}$ in only 15 percent of the samples collected at Devil's Cradle Creek, which has the lowest estimated use $\left(1 \mathrm{lb} / \mathrm{mi}^{2}\right)$ of atrazine. The detection frequencies of atrazine at sites in the Tar-Pamlico drainage basin are similar to detection frequencies of atrazine in agricultural, urban, and integrator sites across the Nation (fig. 5).

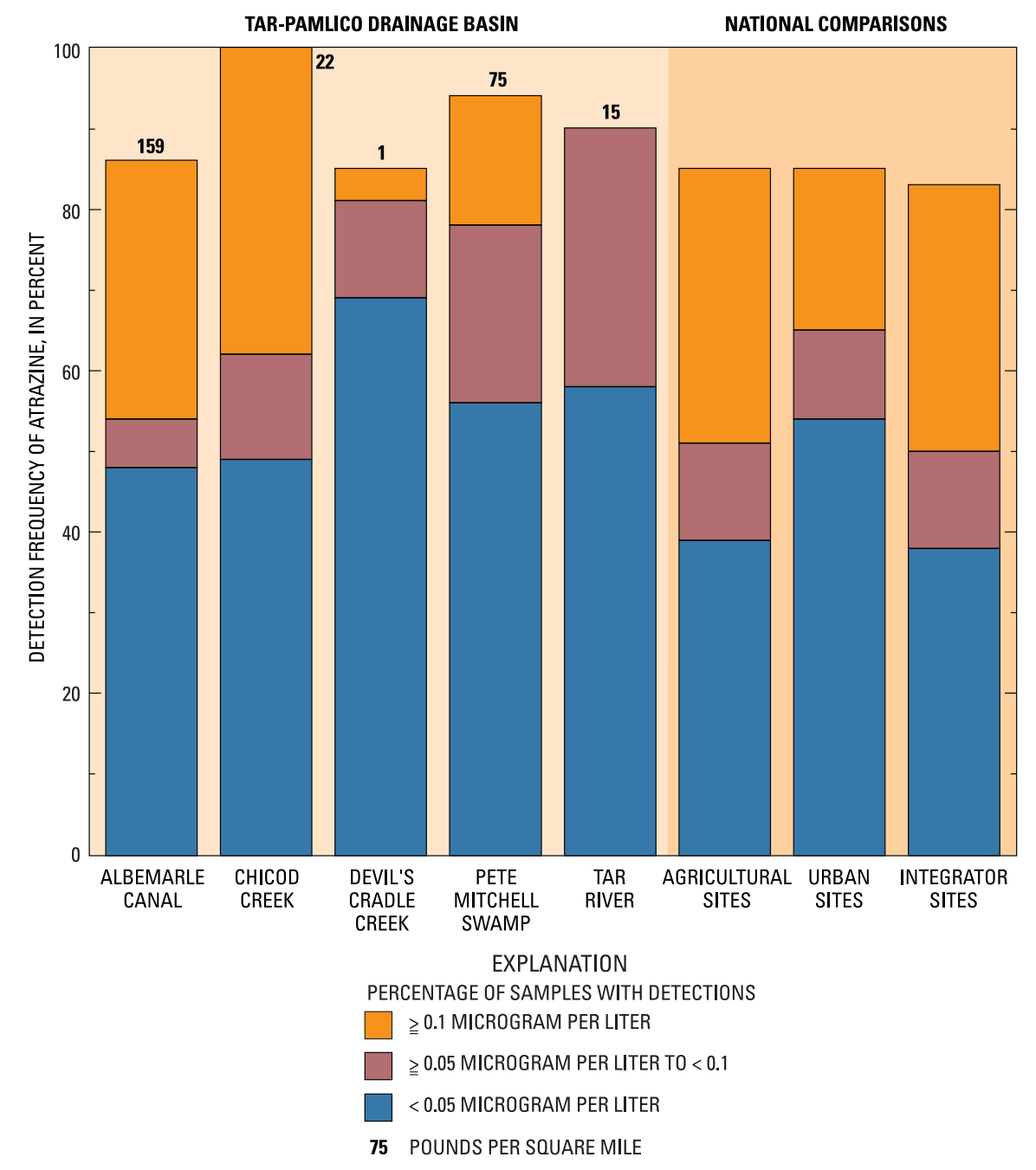

Figure 5. Comparisons of detection frequencies of atrazine in streams in the Tar-Pamlico drainage basin with streams in 62 agricultural, 22 urban, and 31 integrator sites throughout the Nation. 


\section{Alachlor}

Alachlor is used primarily as a preemergent herbicide to control most annual grasses and certain broadleaf weeds in corn, peanuts, and soybeans, which usually are planted by early June in North Carolina. Although concentrations of alachlor vary seasonally, elevated concentrations generally occurred in May, June, and July (fig. 6), which coincides with the application period in the study subbasins. The MCL of $2 \mu \mathrm{g} / \mathrm{L}$ for alachlor in drinking water (U.S. Environmental Protection Agency, 1996) was exceeded in three water samples from Chicod Creek. Alachlor concentrations in Chicod Creek and Albemarle Canal generally were greater than $0.1 \mu \mathrm{g} / \mathrm{L}$ from April to August. At Pete Mitchell Swamp, concentrations of alachlor peaked in May at $0.91 \mu \mathrm{g} / \mathrm{L}$ and generally were greater than $0.01 \mu \mathrm{g} / \mathrm{L}$ throughout the remainder of the sampling period. Concentrations of alachlor in the Tar River generally were less than $0.01 \mu \mathrm{g} / \mathrm{L}$ during the sampling period. Concentrations of alachlor in Devil's Cradle Creek generally were near $0.001 \mu \mathrm{g} / \mathrm{L}$, with several occurrences ranging between 0.003 and $1 \mu \mathrm{g} / \mathrm{L}$ between April and June and during January and February.

There was no relation between alachlor use and detection frequency among sites in the TarPamlico River Basin. Detection frequencies were greater than 90 percent in Albemarle Canal, Chicod Creek, and Pete Mitchell Swamp, but alachlor use varied from $65 \mathrm{lbs} / \mathrm{mi}^{2}$ in Chicod Creek to $223 \mathrm{lbs} / \mathrm{mi}^{2}$ in Albemarle Canal. Alachlor was detected more frequently and at elevated concentrations in Albemarle Canal, Chicod Creek, and Pete Mitchell Swamp when compared to the agricultural sites across the Nation (fig. 7). The detection frequency at Devil's Cradle Creek is low and similar to the national detection frequency for urban streams. The detection frequency for Tar River is similar to the detection frequencies for other integrator sites sampled throughout the Nation.

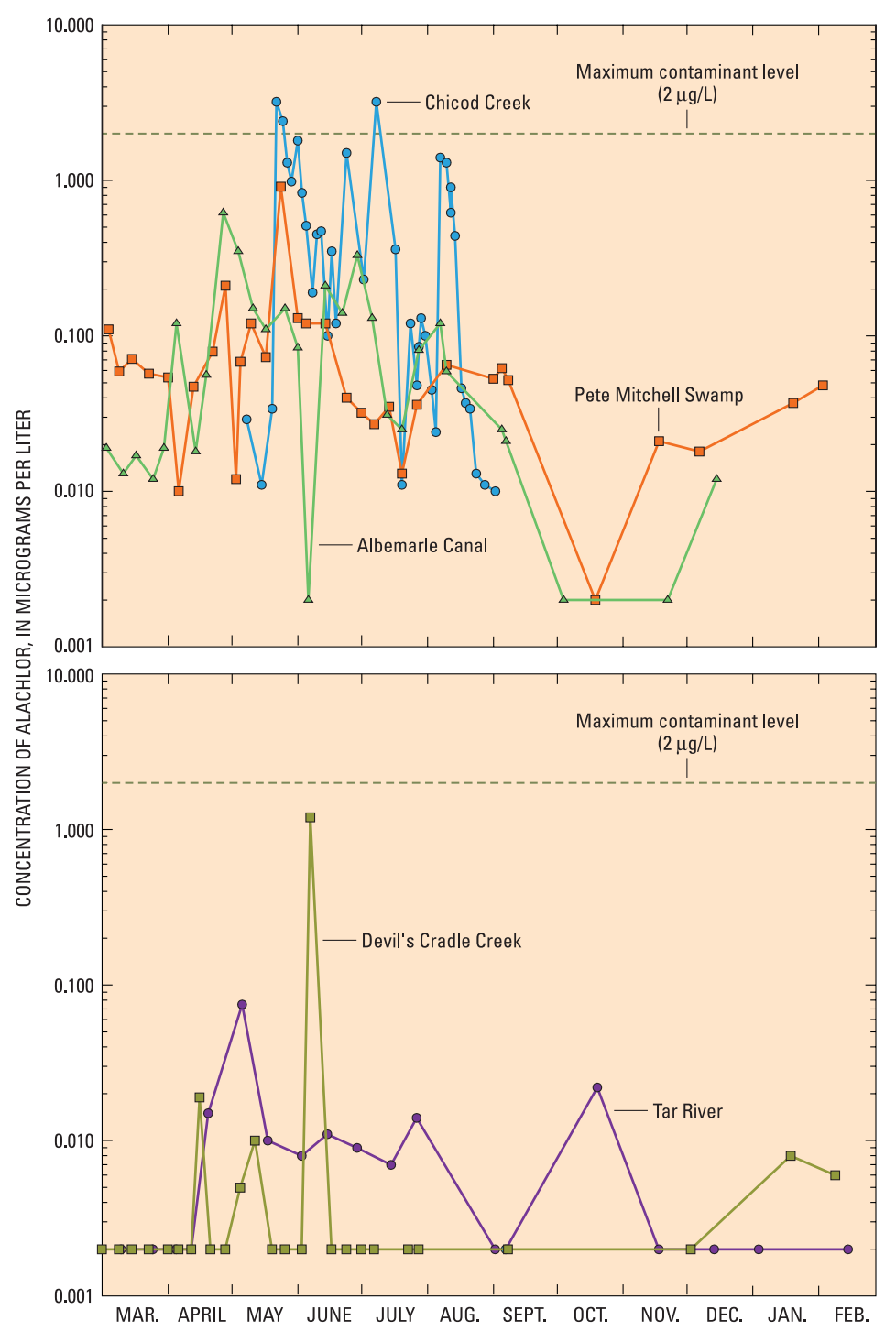

Figure 6. Seasonal variability of alachlor at five sites in the TarPamlico drainage basin, 1992-94. 


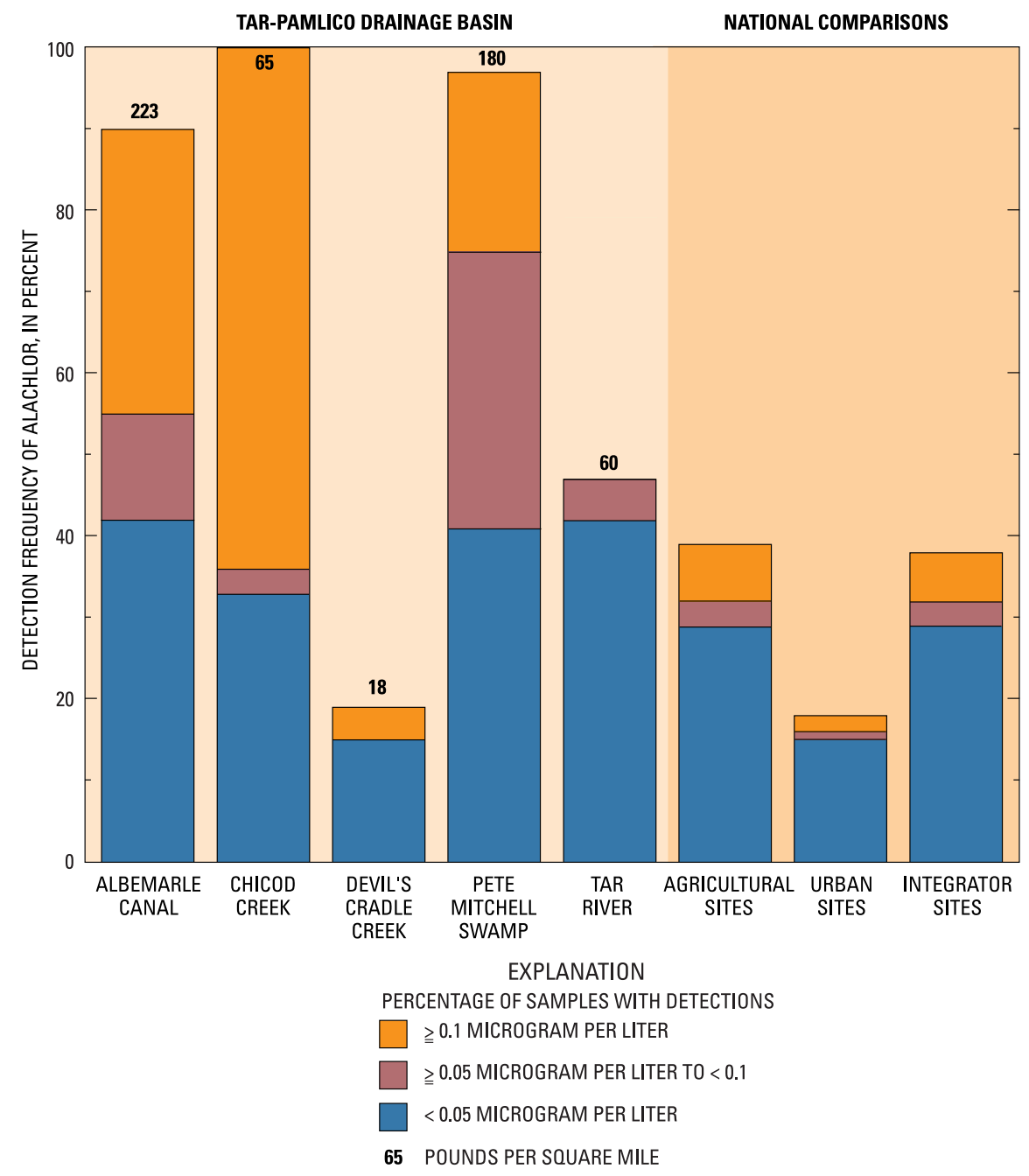

Figure 7. Comparisons of detection frequencies of alachlor in streams in the TarPamlico drainage basin with streams in 62 agricultural, 22 urban, and 31 integrator sites throughout the Nation. 


\section{Prometon}

Prometon is used as a nonselective herbicide in noncrop areas, such as roadways, railways, and industrial areas. Currently (2000), there is no MCL for prometon in drinking-water nor aquatic-life guidelines. No seasonal pattern for prometon concentrations was observed at the indicator sites (fig. 8), probably because prometon use is not related to crop production. The highest concentrations of prometon occurred in June at Chicod Creek; in spring, fall, and winter at Devil's Cradle Creek; and in late summer at Tar River. The maximum recorded concentration of prometon at the indicator sites during the study period was $0.68 \mu \mathrm{g} / \mathrm{L}$ at Chicod Creek.

The detection frequencies of prometon were greater than 60 percent at Chicod Creek and Devil's Cradle Creek (fig. 9). The detection frequencies at Chicod Creek and Devil's Cradle Creek were substantially higher than the national detection frequency for agricultural sites and were similar to the national detection frequency of prometon at urban sites. The detection frequencies of prometon were less than 6 percent at Albemarle Canal and Pete Mitchell Swamp and lower than the detection frequencies at other agricultural sites in the Nation (fig. 9). The frequent detection of prometon, a herbicide not commonly applied to crops, indicates that not all pesticides detected in surface waters are solely related to agricultural sources.

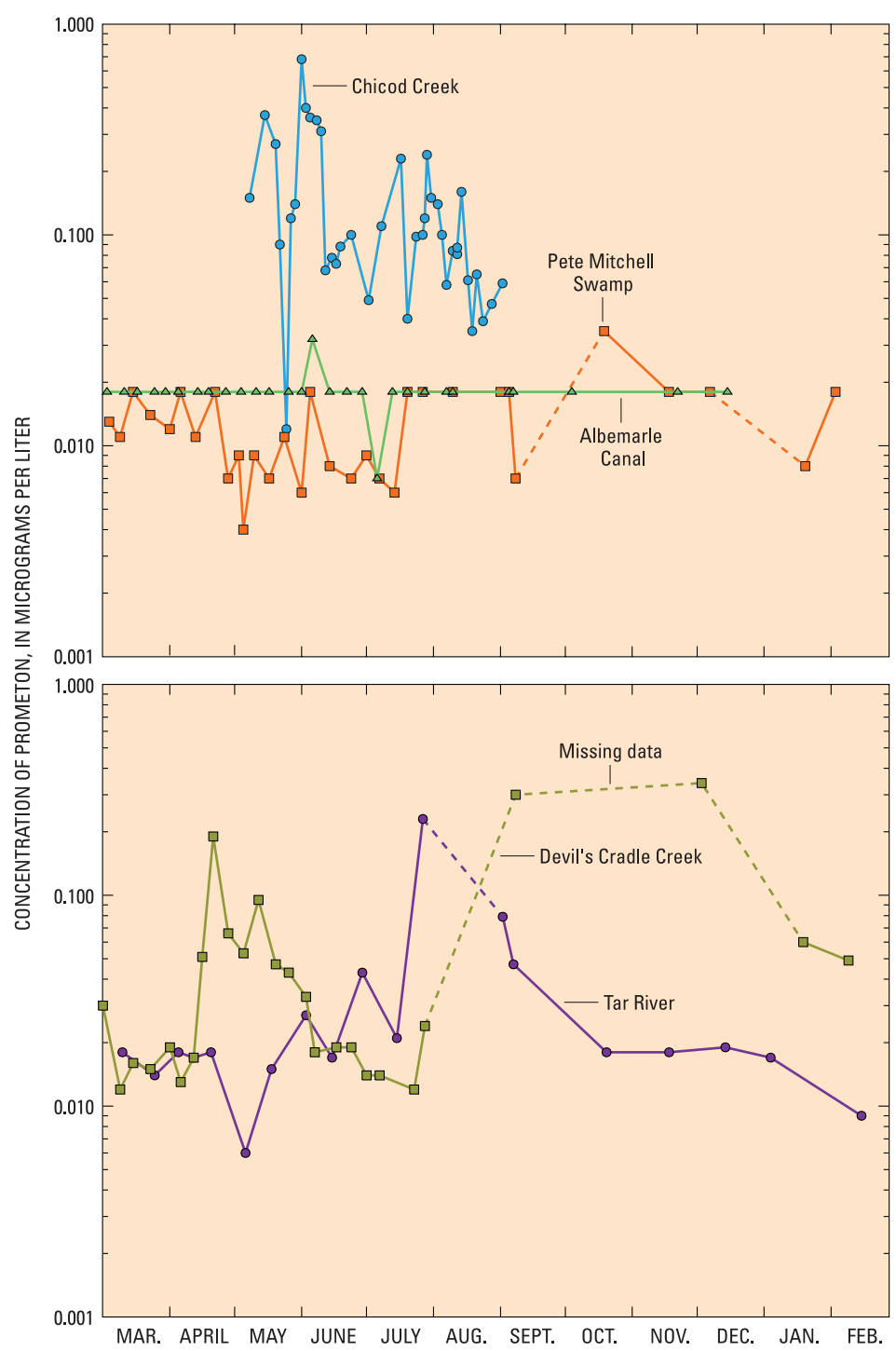

Figure 8. Seasonal variability of prometon at five sites in the TarPamlico drainage basin, 1992-94. 


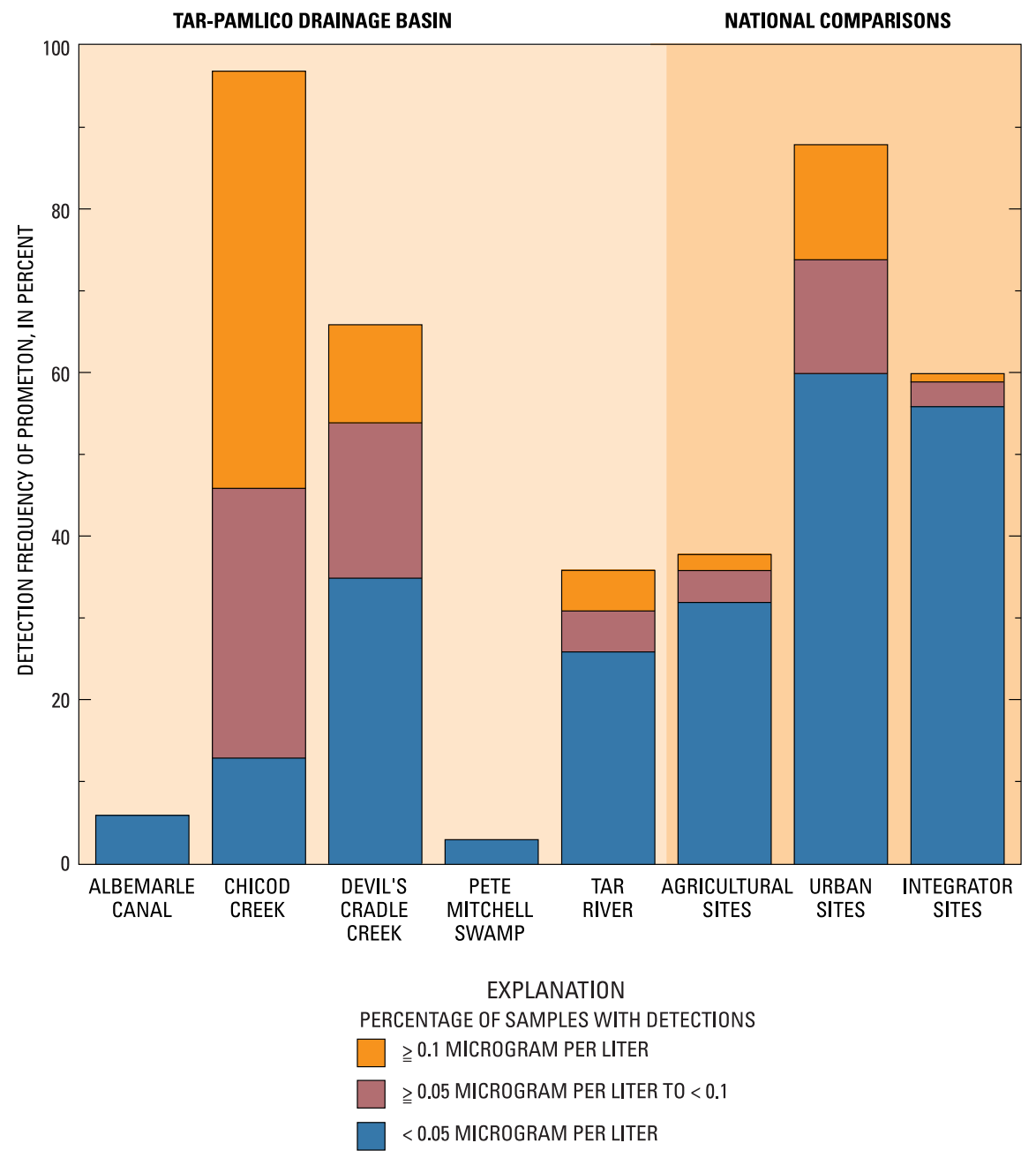

Figure 9. Comparisons of detection frequencies of prometon in streams in the TarPamlico drainage basin with streams in 62 agricultural, 22 urban, and 31 integrator sites throughout the Nation. 


\section{Trifluralin}

Trifluralin is used as a soil-incorporated, preemergent, selective herbicide on numerous crops. During the study period, concentrations of trifluralin peaked at $0.048 \mu \mathrm{g} / \mathrm{L}$ in late April and were elevated throughout May at Pete Mitchell Swamp (fig. 10). Trifluralin concentrations peaked at $0.027 \mu \mathrm{g} / \mathrm{L}$ in June and were elevated in late July and August at Chicod Creek. Concentrations of trifluralin were almost always at the detection level at Albemarle Canal, Devil's Cradle Creek, and the Tar River. There is no current (2000) MCL for trifluralin in drinking water. All concentrations of trifluralin measured during this study were less than the aquatic-life guideline of $0.2 \mu \mathrm{g} / \mathrm{L}$ (Canadian Council of Resource and Environment Ministers, 1991).

No relation was observed between estimated use and detection frequency for trifluralin among the indicator and integrator sites in the Tar-Pamlico drainage basin. The detection frequencies of trifluralin at most sites in the Tar-Pamlico drainage basin were similar to national detection frequencies (fig. 11). The elevated detection frequency of trifluralin at Chicod Creek probably reflects sampling that was restricted to spring and summer months only. All concentrations of trifluralin at Chicod Creek were less than $0.027 \mu \mathrm{g} / \mathrm{L}$.

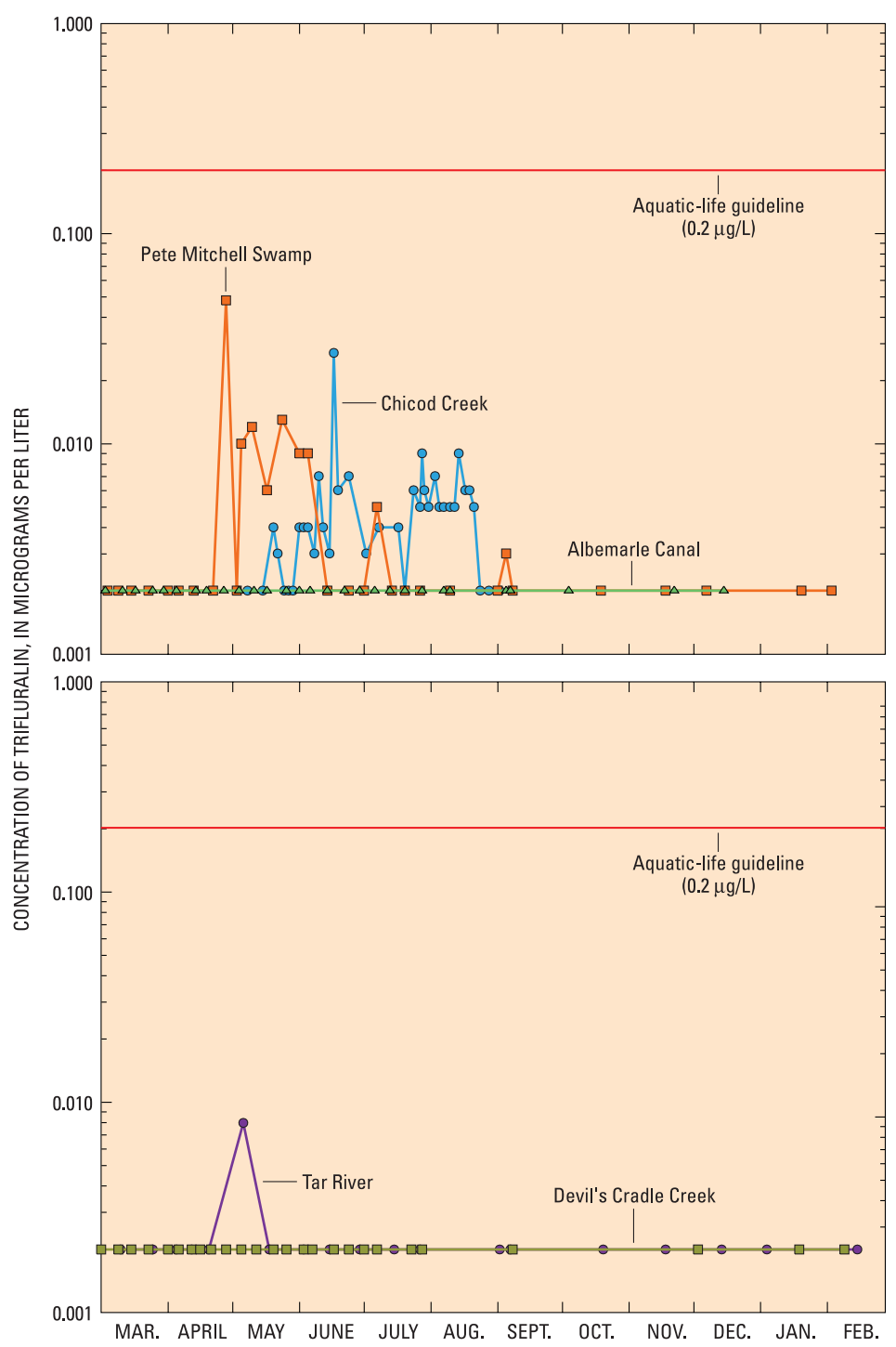

Figure 10. Seasonal variability of trifluralin at five sites in the TarPamlico drainage basin, 1992-94. 


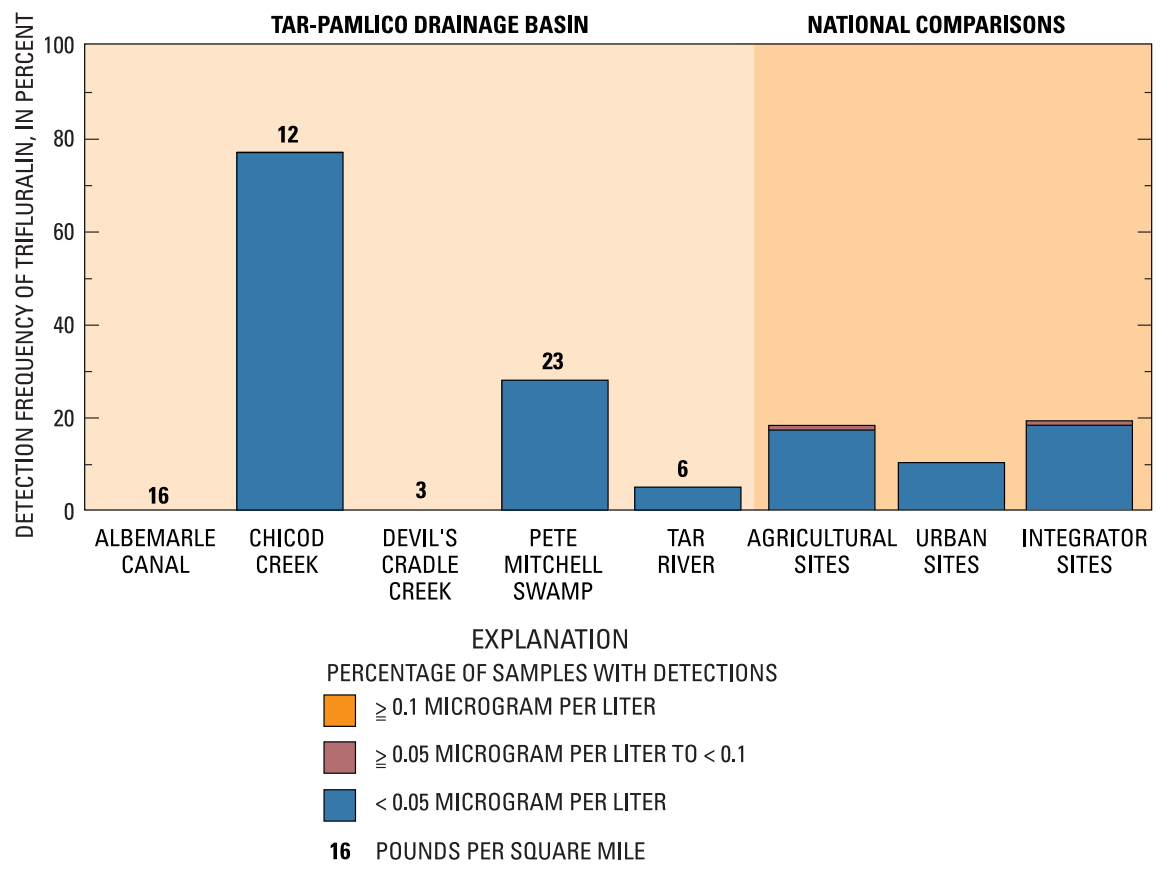

Figure 11. Comparisons of detection frequencies of trifluralin in streams in the Tar-Pamlico drainage basin with streams in 62 agricultural, 22 urban, and 31 integrator sites throughout the Nation. 


\section{Diazinon}

Diazinon is an insecticide that is used in homes, in and around stables, on lawns and crops, and for numerous other purposes. Diazinon concentrations in 4 percent of the water samples collected exceeded the recommended maximum concentration of $0.009 \mu \mathrm{g} / \mathrm{L}$ for the protection of aquatic life (National Academy of Sciences and National Academy of Engineering, 1973). During the study period, concentrations of diazinon were elevated in June and August at Chicod Creek, with a maximum concentration of $0.033 \mu \mathrm{g} / \mathrm{L}$ (fig. 12). Unlike the other pesticides, concentrations of diazinon generally were highest in the Tar River. Concentrations of diazinon in the Tar River began to increase in May and peaked at $0.062 \mu \mathrm{g} / \mathrm{L}$ in July.

There appears to be no relation between estimated use and detection frequencies of diazinon among the indicator and integrator sites in this study. The estimated use of diazinon probably is underestimated, especially in basins draining residential areas, because of the many noncrop uses. The detection frequency of diazinon in the Tar River is similar to the national detection frequency at integrator sites (fig. 13).

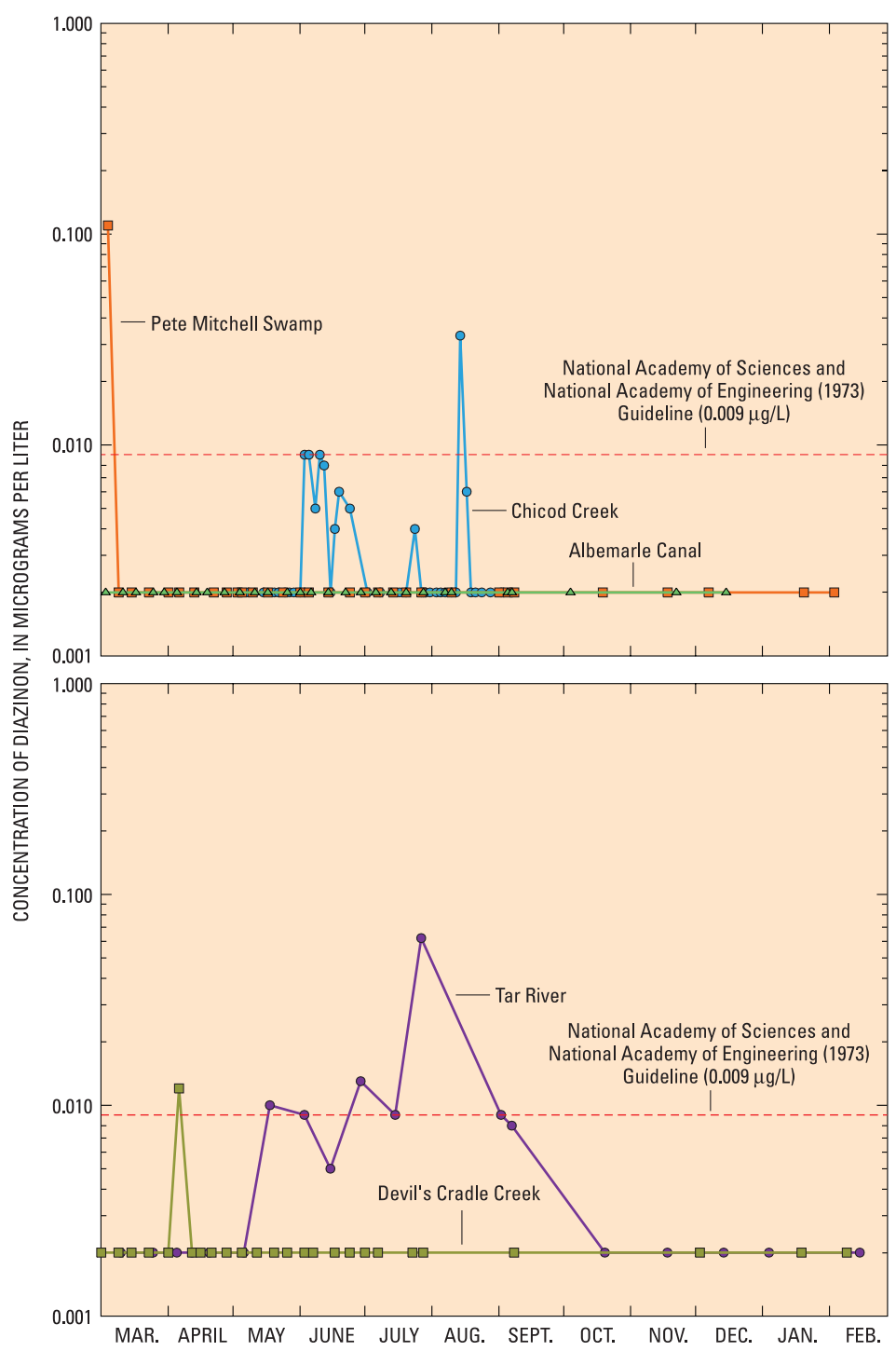

Figure 12. Seasonal variability of diazinon at five sites in the TarPamlico drainage basin, 1992-94. 


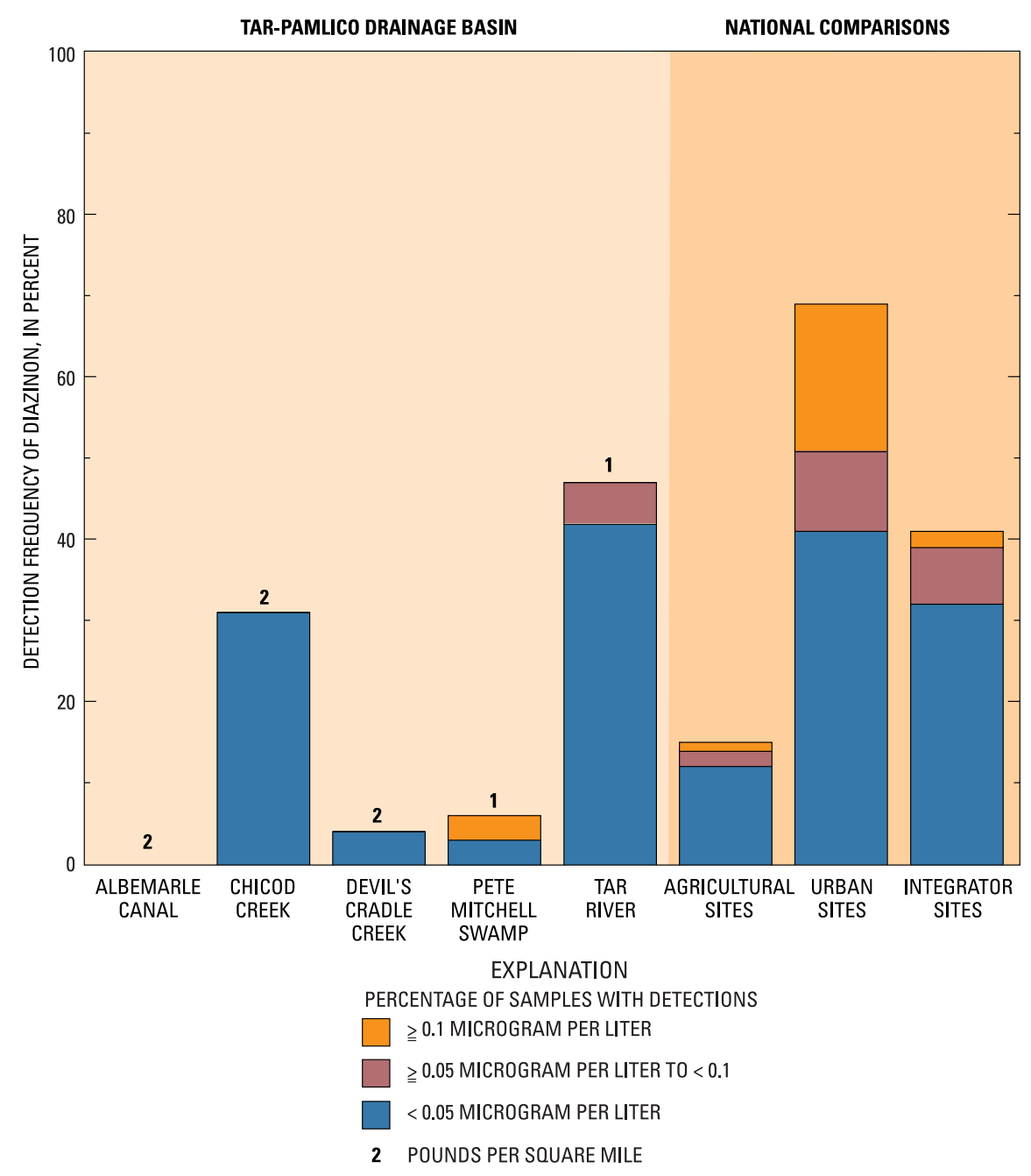

Figure 13. Comparisons of detection frequencies of diazinon in streams in the TarPamlico drainage basin with streams in 62 agricultural, 22 urban, and 31 integrator sites throughout the Nation. 


\section{Chlorpyrifos}

Similar to diazinon, chlorpyrifos is used for domestic and agricultural purposes. Chlorpyrifos is used to control insects in crops, lawns and golf courses, stables and kennels, and in urban areas. Targeted insects commonly are mosquitoes, fleas, and ticks. Chlorpyrifos was detected infrequently at the five sites in the Tar-Pamlico drainage basin (fig. 14). Ambient water-quality criteria for acute exposure of aquatic organisms to chlorpyrifos is $0.083 \mu \mathrm{g} / \mathrm{L}$ (1-hour average concentration) and $0.041 \mu \mathrm{g} / \mathrm{L}$ for chronic exposure (4-day average concentration; Nowell and Resek, 1994). Although ambient water-quality criteria were not exceeded at the indicator or integrator sites, concentrations of chlorpyrifos exceeded the recommended maximum chlorpyrifos concentration for the protection of aquatic life of $0.001 \mu \mathrm{g} / \mathrm{L}$ (National Academy of Sciences and National Academy of Engineering, 1973) at least once at every site (fig. 14), and in 23 percent of the samples collected at Chicod Creek. Detection frequencies of chlorpyrifos at sites in the Tar-Pamlico drainage basin were similar to the national detection frequencies (fig. 15).

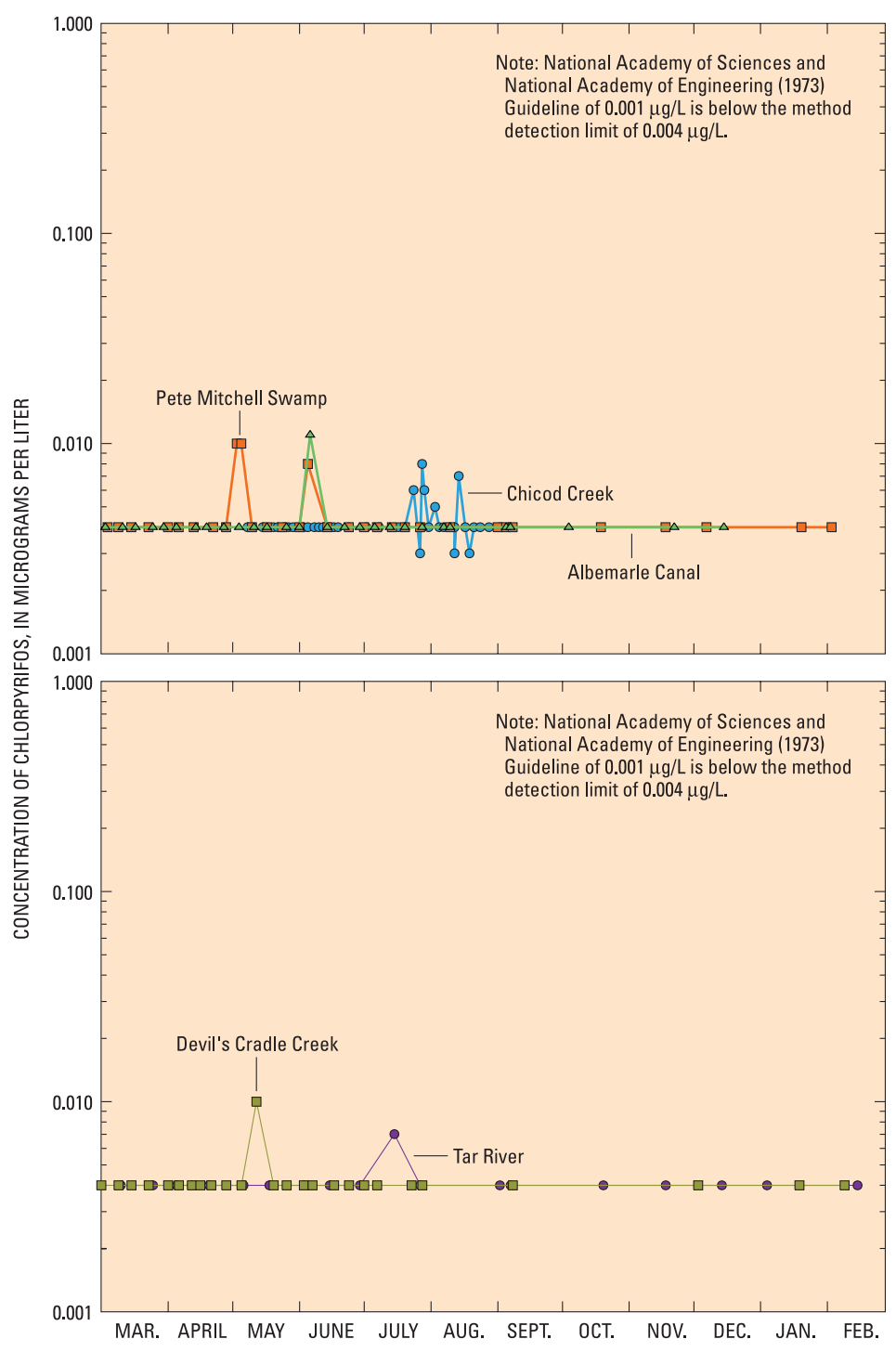

Figure 14. Seasonal variability of chlorpyrifos at five sites in the TarPamlico drainage basin, 1992-94. 


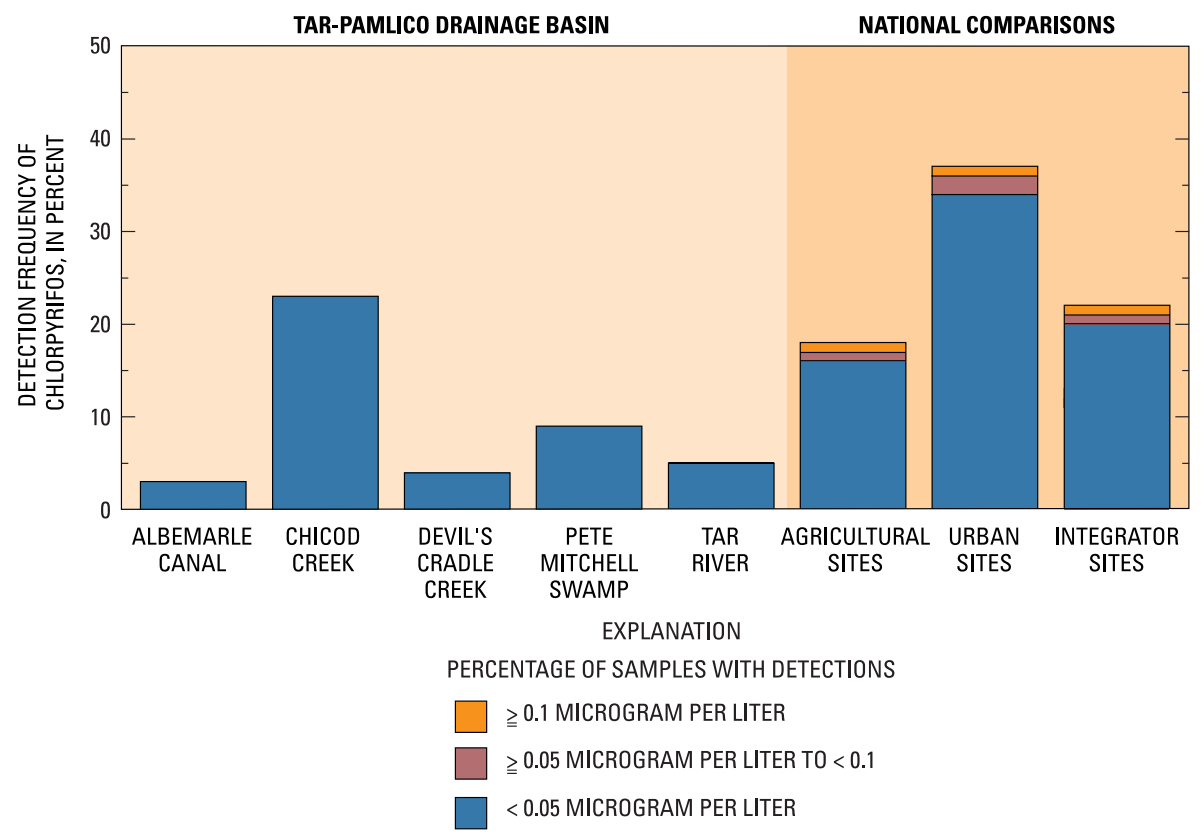

Figure 15. Comparisons of detection frequencies of chlorpyrifos in streams in the TarPamlico drainage basin with streams in 62 agricultural, 22 urban, and 31 integrator sites throughout the Nation.

\section{SUMMARY}

An estimated 455,000 pounds of herbicides and about 90,700 pounds of insecticides were applied in the Tar-Pamlico drainage basin in 1990. During 1992 through 1994, four indicator sites and one integrator site were monitored to assess the occurrence and temporal variability of 46 pesticides. These 46 pesticides accounted for about 73 percent of the estimated herbicide use and 96 percent of the estimated insecticide use in the Tar-Pamlico drainage basin.

Herbicides and insecticides that were detected most frequently at the five sites monitored in the Tar-Pamlico drainage basin also had the highest estimated uses. By using an adjusted detection limit, the most frequently detected herbicides were metolachlor (84 percent), atrazine (78 percent), alachlor (72 percent), and prometon (57 percent). Metolachlor (48,900 lbs), atrazine $(50,100 \mathrm{lbs})$, and alachlor $(130,300 \mathrm{lbs})$ also were the herbicides with the highest estimated uses in the Tar-Pamlico drainage basin. The most frequently detected insecticides were carbaryl (12 percent), carbofuran (7 percent), and diazinon (4 percent). Similar to the herbicides, the most frequently detected insecticides generally had the highest estimated uses. Evaluation of the relation between use and detection frequency is limited by a lack of information on pesticides commonly applied in urban and agricultural areas, such as prometon, chlorpyrifos, and diazinon, and the small number of subbasins included in this study limit. For example, prometon was detected frequently, but no use information was available. Nevertheless, the frequent detection of prometon, a herbicide not commonly applied to crops, indicates that not all pesticides detected in surface waters are solely related to agricultural sources.

Concentrations of the herbicides atrazine, alachlor, and trifluralin varied seasonally with elevated concentrations generally occurring in the spring, during and immediately following application periods, and in the summer. Seasonal concentration patterns were less evident for prometon, diazinon, and chlorpyrifos. Of the two pesticides sampled that have drinking-water standards, only alachlor exceeded current drinking-water standards. Concentrations of alachlor exceeded maximum contaminant levels in less than 2 percent of all surface-water samples collected at five sites in the Tar-Pamlico drainage basin. Guidelines for the protection of aquatic life were infrequently exceeded; however, no drinking-water standards or aquatic-life guidelines currently (2000) exist for many of the pesticides analyzed. 


\section{REFERENCES}

Anderson, J.R., Hardy, E.E., Roach, J.T., and Witmer, R.E., 1976, A land use and land cover classification system for use with remote sensor data: U.S. Geological Survey Professional Paper 964, 28 p.

Barbash, J.E., and Resek, E.A., 1996, Pesticides in ground water-Distribution, trends, and governing factors: Michigan, Ann Arbor Press, Inc., 588 p.

Canadian Council of Resource and Environment Ministers, 1991, Canadian water quality guidelines: Ottawa, Ontario, Environment Canada, Inland Waters Directorate, Water Quality Branch (updated May 1996) [variously paged].

Harned, D.A., McMahon, Gerard, Spruill, T.B., and Woodside, M.D., 1995, Water-quality assessment of the Albemarle-Pamlico drainage basin, North Carolina and Virginia-Characterization of suspended sediment, nutrients, and pesticides: U.S. Geological Survey Open-File Report 95-191, 131 p.

Leahy, P.P., Rosenshein, J.S., and Knopman, D.S., 1990, Implementation plan for the National Water-Quality Assessment Program: U.S. Geological Survey OpenFile Report 90-174, 10 p.

Manning, T.K., Smith, K.E., Wood, C.D., and Williams, J.B., 1994, Pesticide-sampling equipment, sample-collection and processing procedures, and water-quality data at Chicod Creek, North Carolina, 1992: U.S. Geological Survey Open-File Report 94-50, 35 p.

McMahon, Gerard, and Lloyd, O.B., Jr., 1995, Water-quality assessment of the Albemarle-Pamlico drainage basin, North Carolina and Virginia-Environmental setting and water-quality issues: U.S. Geological Survey Open-File Report 95-136, 72 p.

Mueller, D.K., Martin, J.D., and Lopes, T.J., 1997, Qualitycontrol design for surface-water sampling in the
National Water-Quality Assessment Program: U.S. Geological Survey Open-File Report 97-223, 17 p.

National Academy of Sciences and National Academy of Engineering, 1973 [1974], Water quality criteria, 1972: U.S. Environmental Protection Agency, EPA/R3-73-033, 594 p.

Nowell, L.H., and Resek, E.A., 1994, Summary of national standards and guidelines for pesticides in water, bed sediment, and aquatic organisms and their application to water-quality assessments: U.S. Geological Survey Open-File Report 94-44, 115 p.

Sandstrom, M.W., 1990, Sampling requirements for organic contaminants, in Seminar on Management Challenges of New Monitoring Requirements for Organic Chemicals, 1990, Proceedings: American Water Works Association, p. 71-85.

Sandstrom, M.W., Wydoski, D.S., Schroeder, M.P., Zamboni, J.L., and Foreman, W.T., 1992, Methods of analysis by the U.S. Geological Survey National Water Quality Laboratory-Determination of organonitrogen herbicides in water by solid-phase extraction and capillary-column gas chromatography/mass spectrometry with selected-ion monitoring: U.S. Geological Survey Open-File Report 91-519, 26 p.

U.S. Environmental Protection Agency, 1996, Drinking water regulations and health advisories: Washington, D.C., Office of Water, EPA 822-B-96-002, Oct. 1996, $16 \mathrm{p}$.

U.S. Geological Survey, 2000, Data on nutrients in the streams, rivers, and ground water of the United States: accessed on Oct. 1, 2000, at http://water.usgs.gov/ nawqa/nutrients/datasets/cycle91/index.html.

Ware, G.W., 1989, The pesticide book: Fresno, Calif., Thomson Publications, 340 p. 